

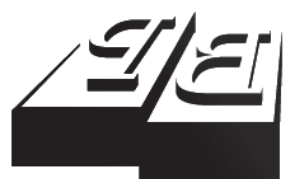

BUSINESS PERSPECTIVES

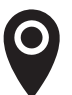

LLC "CPC "Business Perspectives" Hryhorii Skovoroda lane, 10, Sumy, 40022, Ukraine

www.businessperspectives.org

Received on: $23^{\text {rd }}$ of October, 2017 Accepted on: $23^{\text {rd }}$ of November, 2017

(C) Ruslan Mann,

Alexander Bilyk, 2017

Ruslan Mann, D.Sc. (Economics), Associate Professor, Cherkasy State Technological University, Ukraine.

Alexander Bilyk, Ph.D., Professor, Chair of Economics and Business, Cherkasy State Technological University, Ukraine.

\title{
MONITORING THE FACTORS INFLUENCING THE EFFICIENCY OF AGRICULTURAL ENTERPRISES' WORKING CAPITAL OF UKRAINE
}

\begin{abstract}
The efficiency of working capital management is one of the most important activities of any company, because it influences on the continuity of production and sales, the liquidity of the company, its solvency and profitability. To identify the factors influencing on the efficiency of working capital management of Ukrainian agricultural enterprises, systemic approach, analysis and synthesis, evaluation of dynamics structure, factor analysis were used. Profitability is the indicator of the efficiency of current assets. The authors used a modified Dupont model to determine the factors influencing the efficiency of current assets of Ukrainian agricultural enterprises. There was assessed the impact of these factors on the profitability of current assets and the stability of economic growth of Ukrainian agricultural enterprises in the period 2013-2015. The most influential factors of efficiency of current assets of agricultural enterprises were developed. The impact of selected factors on the stability of economic growth of Ukrainian agricultural enterprises was assessed.
\end{abstract}

Keywords

JEL Classification sustainability of economic growth

D24, G31, Q14

\section{INTRODUCTION}

Current assets are one of the most important resources providing the economic activity of any company. Therefore, it is necessary to organize effective working capital management process, including its formation, distribution and using. The efficiency of working capital management is an important part of the company activity, because it affects production and sales of goods and services liquidity, solvency and profitability of the company. Favorable climatic conditions and the presence of large reserves of fertile soils create conditions for the development of agriculture, which is one of the most important sectors of Ukraine's economy. Thus, in 2015, the agriculture companies provided $24 \%$ of the manufactured products, $18 \%$ of GDP and $38.2 \%$ of merchandise exports of Ukraine. Therefore, according to the current economic situation, the research of factors influencing the efficiency of working capital management of agricultural enterprises is very significant.

Research goal. The purpose of the article is to research the factors influencing the efficiency of working capital management of Ukrainian agricultural enterprises at the present stage of the economy. 


\section{LITERATURE REVIEW}

The research of methods of influence on the efficiency of working capital management companies is investigated by many Ukrainian scholars, including Ivanina (2012), Semenov and Bugay (2008), Kruta (2014). Achievements of foreign scientists deserve the special attention. Sefideh and Asgari (2016) investigated the impact of working capital policy on risk management in Tehran companies. The results show that among the four criteria of profitability and working capital policy, return on assets, return on equity, return on investment and Tobin's $Q$, there is a direct relationship. The results confirm that the between policy and operational risk and financial risk, working capital and an inverse relationship exists.

In Faris Nasif ALShubiri's (2011) opinion, the goal of working capital management is the management of the net of current assets and current liabilities with the objective of reaching the right balance between profitability and liquidity. The author says that efficient working capital is a prerequisite to growth and existence of corporate enterprises, because it dictates the level of production, inventory and sales. The result indicates that when any company manages its working capital well, it has every leverage opportunity to continue in business indefinitely both in profitability and in liquidity.

Oseifuah and Gyekye (2017) explain the existence of relationships between company value and policy of working capital management. There was defined the significant positive relationship between company value and both inventory conversion period and receivables conversion period; between accounts payable deferral period and profitability. In addition, there is a vital negative relationship between leverage and company value.

Consequently, the authors consider various factors affecting the efficiency of working capital management. But common main objective of working capital management is to provide the required size of profitability and liquidity.

Thus, in the works of Isberg (1998), Dragana (2016), and Jezovita (2015), the financial analysis of the company by using the Du Pont model is described.
Ulanchuk, Zharun, Sokolyuk, and Tkachuk (2017) investigate the role of investments for the development of material and technical basis of agricultural enterprises. Sievidova (2017) researches the factors affecting the economic management efficiency of agricultural enterprises in Ukraine. The main issues are defining the direction of development and forming the optimal business strategy of agricultural enterprises. One of the most significant components is development of production and resource potential of agricultural enterprises.

However, the impact on the efficiency of working capital management of agricultural enterprises is not sufficiently studied. As agriculture is one of the most important sectors of Ukrainian economy, studying the efficiency of working capital management of this sector is very topical.

\section{METHODS AND MATERIALS OF STUDY}

Significant indicator of the efficiency of working capital management on a company is the rate of current assets profitability, which demonstrates the expediency of financial management policy. That is why the study of the research is based on Dupont formula (Isberg, 1998, p. 2; Dragana, 2016, p. 552) combining two main impact facm tors on profitability of current assets, namely the change of sales profitability and the change of turnover of current assets. The most substantial role in the profit formation belongs to sales volume, which is one of the main indicators of business activity. In this regard, it is advisable to investigate its impact on the change of profitability of current assets.

For this, the rate of sales is added to the formula of profitability of current assets (formula 1) (Ivanina, 2012, p. 113).

$$
K_{P C A}=\frac{P}{S R} \cdot \frac{I}{C A},
$$

where $P$ - the value of profit, UAH; $I$ - income, $\mathrm{UAH}$; $C A$ - the value of current assets, UAH.

In turn, these two complex factors can be divided into elementary components (Figure 1), formulae 2-3. 


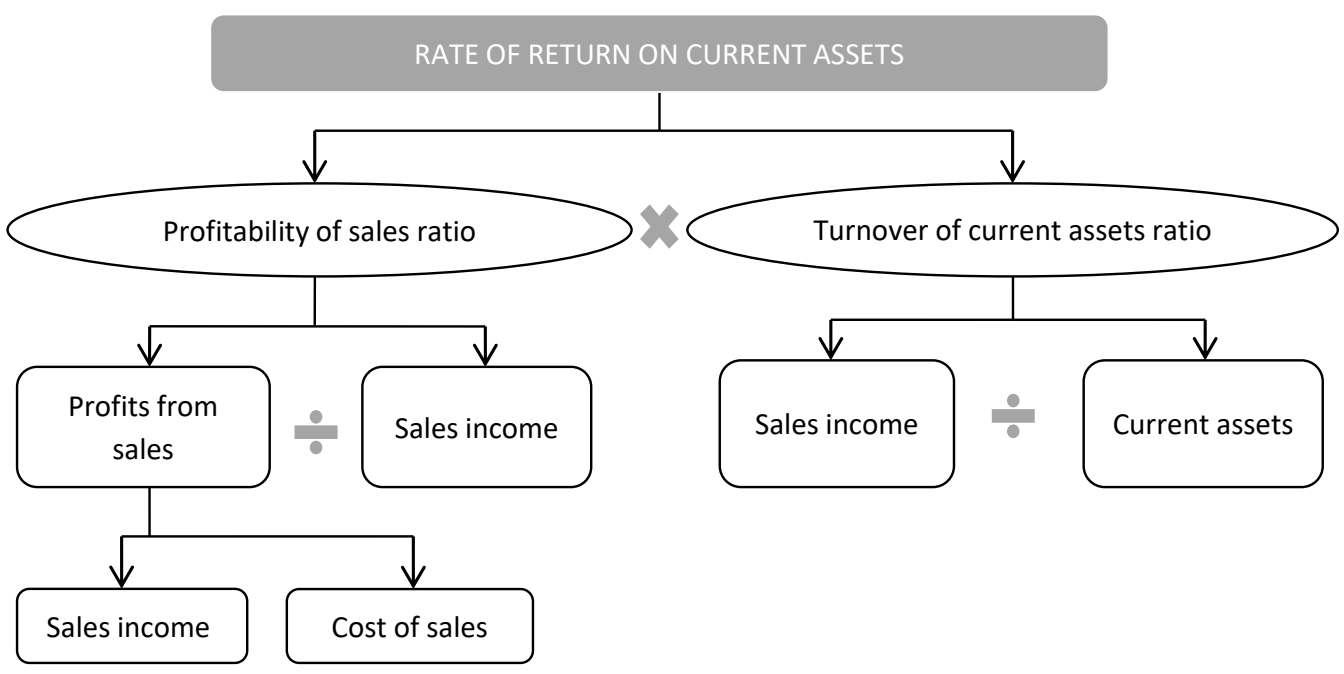

Figure 1. The structural and logical model of influence factors on the rate of return of current assets

$$
\begin{aligned}
& K_{P S R}=\frac{P}{I}=\frac{I-C}{I}, \\
& K_{T C A}=\frac{I}{C A}=\frac{I}{S+R+M},
\end{aligned}
$$

where $K_{P S R}$ - profitability of sales ratio; $K_{T C A}-$ turnover of current assets ratio; $C$ - cost of sales, $\mathrm{UAH}$; $S$ - the value of inventories, UAH; $R$ - the value of receivables, $\mathrm{UAH} ; M$ - the value of money funds, UAH.

For the determination the degree of influence the factors on increase of profitability of current assets, the method of proportional division based on the initial information Table 1 is used. The calculation is performed as follows (formula 4).

$$
\mid \begin{aligned}
& \Delta y_{a}=\frac{\Delta y_{z a g}}{\Delta a+\ldots+\Delta n} \cdot \Delta a, \\
& \Delta y_{n}=\frac{\Delta y_{z a g}}{\Delta a+\ldots+\Delta n} \cdot \Delta n,
\end{aligned}
$$

where $\Delta y_{a}, \Delta y_{n}$ - the increase of the effective rate due to the influence of the factors $(a, n)$ (Ježovita, 2015, p. 113).

\section{RESULTS}

As the indicator of efficiency of using current assets, the profitability is the indicator of the quality of management and the ability to generate revenue for the formation of the required amount of own

Table 1. Statistical data of Ukrainian agricultural enterprises used to calculate the impact of factors

\begin{tabular}{|c|c|c|c|c|}
\hline No & Indicator & 2013 & 2015 & $\begin{array}{c}\text { Deviation } \\
(+/-)\end{array}$ \\
\hline 1 & Rate of return on current assets, $\%$ & 7.6 & 19.9 & 12.3 \\
\hline 2 & Profitability of sales ratio, $\%$ & 9.3 & 28.4 & 19.1 \\
\hline 3 & Turnover of current assets ratio & 0.93 & 0.51 & -0.42 \\
\hline 4 & Income, mln. UAH & 26186.6 & 127360,1 & 101174 \\
\hline 5 & The average value of current assets, mln. UAH & 195021 & 514625 & 319603 \\
\hline 6 & The average annual value of inventories, mln. UAH & 66754 & 114925 & 48170.7 \\
\hline 7 & The average value of receivables, mln. UAH & 98290 & 342783 & 244492 \\
\hline 8 & Average cost of money funds, mln. UAH & 9885.4 & 16771 & 6885.5 \\
\hline
\end{tabular}
on the profitability of current assets

Source: elaborated by the author based on (State Statistics Service of Ukraine, 2016). 
working capital. The last one is the basis for sustainable financing of current assets (Table 1).

The level of influence of factors on change of factor of profitability of current assets of Ukrainian agricultural enterprises is calculated.

1. The change of profitability of sales ratio: $12.3 /(41.9-19.1) \cdot 19.1=10.3$.

2. The change of turnover of current assets ratio: $12.3 /(41.9-19.1) \cdot(-41.9)=-22.6$.

As the turnover ratio of current assets has the most significant effect $(-22.6)$, the impact factors of the second order to the change of this indicator will be explored:

a. the change of sales revenue: $-22.6 /(101174-319603) \cdot 101174=10.47$;

b. the change of current assets amount: $-22.6 /(101174-319603) \cdot(-319603)=-33.07$.

Audit: $-33.07+10.47=-22.6$.

The influence on the change of the amount of current assets is implemented by:

a. the change of inventories:

$-33.07 /(48170.7+244492+6885.5) \times$

$\times 48170.7=-5.32$

b. the change of receivables:

$-33.07 /(48170.7+244492+6885.5) \times$

$\times 244492=-26.99$

c. the change of money funds:

$-33.07 /(48170.7+244492+6885.5) \times$

$\times \cdot 6885.5=-0.76$.

Audit: $-5.32-26.99-0.76=-33.07$.

Therefore, the analysis of the factors of changes the profitability of current assets of Ukrainian agricultural enterprises shows that a significant effect on the increase of this indicator ( -22.6 points) has the turnover ratio of current assets. In particular, it is shown by reducing the amount of current assets by 33.07 points, including inventories (5.32 points), accounts receivable (26.99 points), money funds ( 0.76 points). The growth of the profitability of sales ratio will boost the rate of return of current assets.

Based on calculation the influence of factors on change the profitability of current assets the most influenced on the performance of the company factors can be identified. Taking into account the changes in business helps to manage the working capital efficiently. In particular, the analysis of Ukrainian agricultural enterprises indicates about no effective receivables policy of enterprises (the share of debt in total current assets is 66.61\%).

The business activity of any enterprise is characterized by degree of sustainability of economic growth: its ability to provide the optimal ratio at financing the growth of capital by used own and borrowed resources to achieve value maximization of capital. The opportunities of enterprises to expand their activities are defined by the stability of growth index, that shows the growth rate of economic capacity of enterprises (Abramova, 2014, p. 31; Shyndyruk, 2012, p. 113).

To assess the impact of factors on the sustainable development of enterprises it is useful to use the next one model (formula 5) (Kruta, 2014, p. 143):

$K_{f s}=\frac{R P}{N P} \cdot \frac{N P}{S R} \cdot \frac{S R}{O W C} \cdot \frac{O W C}{C A} \cdot \frac{C A}{C L} \cdot \frac{C L}{C} \cdot \frac{C}{E}=$

$=K_{e r} \cdot K_{s} \cdot K_{t w} \cdot K_{s} \cdot K_{l} \cdot K_{c l} \cdot K_{f d}$,

where $K_{f s}$ - the factor of stability of economic growth; $R P$ - the reinvested profit; $N P$ - the net profit; $I$ - the income; $O W C$ - the own working capital; $C A$ - the current assets; $C L$ - the current liabilities; $C$ - the capital (balance sheet); $E$ - the equity; $K_{e r}, K_{s}, K_{t w}, K_{s}, K_{l}, K_{c l}, K_{f d}$ in accordance, the share of earnings reinvested in manufacturing; the return on sales; the turnover ratio of own working capital; the ratio of sufficiency of own working capital; the current liquidity; the share of current liabilities in the capital of the company; the ratio of financial dependence.

Thus, the stability of enterprises economic growth is formed by the factors which provide the financing of current assets (the ratio of sufficiency of own working capital, the current liquidity, the share of current liabilities in the 
Table 2. The factor analysis of stability of economic growth of Ukrainian agricultural enterprises in the period 2013-2015, mln. UAH

Source: elaborated by the author based on (State Statistics Service of Ukraine, 2016).

\begin{tabular}{|c|c|c|c|c|c|}
\hline No & Indicator & 2013 & 2015 & $\begin{array}{l}\text { Deviation } \\
(+/-)\end{array}$ & $\begin{array}{l}\text { The exchange } \\
\text { of } K_{f s} \text {, points }\end{array}$ \\
\hline 1 & Net profit & 14984.5 & 102849 & 87864.6 & - \\
\hline 2 & Earnings reinvested in manufacturing & 9739.93 & 69937.39 & 60197.5 & - \\
\hline 3 & Income & 181130 & 262310 & 81179.7 & - \\
\hline 4 & Balance sheet & 313097 & 685845 & 372748 & - \\
\hline 5 & The average value of current assets & 195021 & 514625 & 319603 & - \\
\hline 6 & The average value of own working capital & 71840.3 & 173865.3 & 102025 & - \\
\hline 7 & The average value of equity & 156820 & 275304 & 118484 & - \\
\hline 8 & The average value of current liabilities & 113181 & 342359 & 229178 & - \\
\hline 9 & Reinvested profit & 0.650 & 0.680 & 0.030 & 0.47 \\
\hline 10 & Return on sales, \% & 9.300 & 28.400 & 19.100 & 7.14 \\
\hline 11 & Turnover of working capital, times & 2.521 & 1.509 & -1.013 & -7.1 \\
\hline 12 & The ratio of sufficiency of own working capital & 0.229 & 0.254 & 0.024 & 0.85 \\
\hline 13 & The current liquidity & 1.133 & 1.167 & 0.034 & 0.022 \\
\hline 14 & $\begin{array}{l}\text { The share of current liabilities in the capital of the } \\
\text { company }\end{array}$ & 0.361 & 0.499 & 0.138 & 0.006 \\
\hline 15 & The ratio of financial dependence & 1.997 & 2.491 & 0.495 & 0.001 \\
\hline 16 & The factor of stability of economic growth, \% & 2.860 & 10.724 & 7.863 & 1.389 \\
\hline
\end{tabular}

capital of the company, the ratio of financial dependence, the reinvested profit) and characterize the effectiveness of its use (the turnover ratio of own working capital, the net profit, the sales revenue).

The factor analysis of the dynamic of the factor of stability of economic growth of Ukrainian agricultural enterprises is presented in Table 2. According to this table, the factor of stability of economic growth increased by 0.249 points.

The increase of the share of reinvested earnings by 0.03 points led the increase of $K_{f s}$ by 0.47 points:

$$
K_{f s}=0.03 \cdot 28.4 \cdot 1.51 \cdot 0.25 \cdot 1.17 \cdot 0.5 \cdot 2.49=+0.47 .
$$

1. The increase the return on sales by 19.1 points led the increase of $K_{f s}$ by 7.14 points:

$$
K_{f s}=0.68 \cdot 19.1 \cdot 1.51 \cdot 0.25 \cdot 1.17 \cdot 0.5 \cdot 2.49=+7.14 \text {. }
$$

2. The reducing the number of turns on own working capital by 1.01 points led the decrease of $K_{f s}$ by 7.1 points:

$K_{f s}=-0.68 \cdot 28.4 \cdot 1.01 \cdot 0.25 \cdot 1.17 \cdot 0.5 \cdot 2.49=-7.1$.
3. The growth the degree of providing by own working capital by 0.02 points led the increase of $K_{f s}$ by 0.85 points:

$K_{f s}=0.68 \cdot 28.4 \cdot 1.51 \cdot 0.02 \cdot 1.17 \cdot 0.5 \cdot 2.49=+0.85$.

4. The growth the current liquidity by 0.03 points led the increase of $K_{f s}$ by 0.022 points:

$K_{f s}=0.68 \cdot 28.4 \cdot 1.51 \cdot 0.02 \cdot 0.03 \cdot 0.5 \cdot 2.49=+0.022$.

5. The growth the share of current liabilities in the capital of the company by 0.14 points led the increase of $K_{f s}$ by 0,006 points:

$K_{f s}=0.68 \cdot 28.4 \cdot 1.51 \cdot 0.02 \cdot 0.03 \cdot 0.14 \cdot 2.49=+0.006$.

6. The growth the ratio of financial dependence by 0.49 points led the increase of $K_{f s}$ by 0.001 points:

$$
K_{f s}=0.68 \cdot 28.4 \cdot 1.51 \cdot 0.02 \cdot 0.03 \cdot 0.14 \cdot 0.49=+0.001 .
$$

The total increase of the factor of stability of economic growth is (in points):

$0.47+7.14-7.1+0.85+0.022+0.006+0.001=+1.389$. 
Thus, the enterprises of agricultural sector have the minor rate of economic growth (1.389). It provided the increase of profitability of product sales (7.14), of degree of provision by own working capital (0.85); of current liquidity ratio (0.022) (particularly due to the increase of work in progress); the rational capital structure. The deceleration of turnover of own working assets (due to the growth of inventories and receivables) impedes the economic growth of enterprises.

The efficient use of resources (increase of turnover of current assets) contributes to increase the efficiency of using working capital. Reducing the efficient use of current assets leads to its additional attraction, that negatively affects on enterprises. It is important to follow some recommendations, such as: establishing reasonable standards of production; standardization of production technology; purchasing the fertilizers at wholesale prices, using the analogues; minimization the costs of acquisition, transportation and storage of inventories; optimization of residual components of current resources.

It is useful to reduce the amount of receivables by cutting down the period of repayment, namely: to develop the methods of evaluation the reliability of customers; to increase the number of buyers in order to minimize the losses from non-payment of several buyers; to identify the doubtful debts in time. It will not only provide the improving of financial condition of agricultural enterprises, but also it will increase its performance overall, longterm solvency and profitability.

\section{CONCLUSION}

Profitability is one of the most significant factors which points to the efficiency of current assets using. The research is based on the data of Ukrainian agricultural enterprises in 2013-2015 years, in particular: net profit, income, return on sales, current liquidity, ratio of financial dependence and other financial ratios. Among the investigated factors, the greatest impact on the profitability of current assets of Ukrainian agricultural enterprises is created by the change of turnover of current assets (-22.6 points), the change of amount of current assets ( -33.07 points), the change of amount of receivables $(-26.99$ points). The factor analysis of the dynamic of the factor of stability of economic growth of Ukrainian agricultural enterprises showed that the number of turnover of current assets (-7.1 points) and the return on sales (7.14 points) had the greatest impact.

Therefore, it is proposed to introduce the measures of growth the efficient use of resources, of improve the relations with partners, of improve accounts receivable policy. The prospect of further research is determination the causes of growth the amount of inventories and receivables at Ukrainian agricultural enterprises and finding ways to eliminate these shortcomings with a view to increase the turnover of current assets and, consequently, the efficiency of economic activity.

\section{REFERENCES}

1. Abramova, I. M. (2014).

Управління запасом фінансової стійкості підприємства [Upravlinnia zapasom finansovoi stiikosti pidpryiemstva]. Zovnishnia torhivlia: ekonomika, finansy, pravo, 2, 30-36.

2. Dragana, D. (2016). Comparative analysis of functional food produce rs' profitability in Serbia: A leaderfollower relation. Economics of Agriculture, 2, 547-566.
3. Faris Nasif ALShubiri (2011). The effect of working capital practices on risk management: evidence from Jordan. Global journal of business research, 5(1), 39-54.

4. Isberg, S. C. (1998). Financial analysis with the Du Pont ratio: A useful compass. Credit \& Financial Management Review, Second Quarter, 1-4.

5. Ivanina, A. V. (2012). Вітчизняний та зарубіжний досвід оцінки ефективності використання фінансових ресурсів підприємства [Vitchyznianyi ta zarubizhnyi dosvid otsinky efektyvnosti vykorystannia finansovykh resursiv pidpryiemstva]. Upravlinnia rozvytkom, 12 , 112-115.

6. Ježovita, A. (2015). Designing the model for evaluating financial quality of business operations - evidence from Croatia. Management, 20(1), 101-129. 
7. Kruta, L. S. (2014). Оцінка впливу структури оборотних активів на ділову активність підприємства [Otsinka vplyvu struktury oborotnykh aktyviv na dilovu aktyvnist pidpryiemstva]. Upravlinnia rozvytkom, 15, 141-144.

8. Oseifuah, E. K., \& Gyekye, A. (2017). Working capital management and shareholders' wealth creation: evidence from non-financial firms listed on the Johannesburg Stock Exchange. Investment Management and Financial Innovations, 14(1), 80-88.

9. Sefideh, S. R., \& Asgari, M. R. (2016). The impact of working capital policy on risk management in the companies listed in Tehran Stock Exchange. Problems and Perspectives in Management, 14(3si). http://dx.doi.org/10.21511/ ppm.14(3-si).2016.09
10. Semenov, G. A., \& Bugay, A. V. (2008). Факторний аналіз рентабельності оборотних активів машинобудівних підприємств [Faktornyi analiz rentabelnosti oborotnykh aktyviv machynobudivnykh pidpryiemstv]. Visnyk Zaporizkoho natsionalnoho universytetu, 3(1), 137-143.

11. Shyndyruk, I. P. (2012). Економіко-математичне моделювання та оптимізація структури капіталу підприємств [Ekonomikomatematychne modeliuvannia ta optymizatsiia struktury kapitalu pidpryiemstv]. Finansy Ukrainy, 2, 111-118.

12. Sievidova, I. A. (2017). Factors affecting the economic management efficiency of agricultural enterprises in Ukraine. Problems and
Perspectives in Management, 15(2-1), 204-211. http://dx.doi. org/10.21511/ppm.15(2

1). 2017.04

13. State Statistics Service of Ukraine (2016). Agriculture of Ukraine - 2015. Retrieved from http:// ukrstat.org/uk/druk/publicat/ kat_u/publ7_u.htm

14. State Statistics Service of Ukraine (2016). The activities of enterprises. Retrieved from http://www. ukrstat.gov.ua

15. Ulanchuk, V., Zharun, O., Sokolyuk, S., \& Tkachuk, S. (2017). Investment needs assessment of Ukrainian agricultural enterprises. Investment Management and Financial Innovations, 14(11), 181-190. http://dx.doi. org/10.21511/imfi.14(1-1).2017.04 